EVANGELOS KOUTSOUKOS ${ }^{\mathrm{a}, \mathrm{b}}$ - CHRISTOS KAZILAS ${ }^{\mathrm{c}, \mathrm{d}}$

\title{
ADDRESSING DISTRIBUTIONAL SHORTCOMINGS THROUGH CITIZEN SCIENCE RECORDS: THE PRESENCE OF HERMETIA ILLUCENS (LINNAEUS, 1758) (DIPTERA STRATIOMYIDAE) IN ALGERIA
}

\author{
a Section of Ecology and Systematics, Department of Biology, National and Kapodistrian University of Athens, \\ 15784 Athens, Greece \\ ${ }^{b}$ Museum of Zoology, National and Kapodistrian University of Athens, 15784 Athens, Greece \\ ${ }^{c}$ Naturalis Biodiversity Center, PO Box 9517, 2300 RA Leiden, The Netherlands \\ ${ }^{d}$ Institute of Biology, Leiden University, Sylvius Laboratory, Sylviusweg 72, 2333 BE, Leiden, The Netherlands \\ Corresponding Author: Christos Kazilas; email: ckazilas@gmail.com
}

Koutsoukos E., Kazilas C. - Addressing distributional shortcomings through citizen science records: the presence of Hermetia illucens (Linnaeus, 1758) (Diptera Stratiomyidae) in Algeria.

\begin{abstract}
The black soldier fly, Hermetia illucens (Linnaeus, 1758) (Diptera: Stratiomyidae) is a polysaprophagous species originating from the Nearctic, that has been introduced to various countries throughout the world over the past decades. Even though, the fly has been recorded in several parts of the Mediterranean region and southern Africa, to this day its presence from northern Africa is only known from Morocco. The current study provides the first record of the black soldier fly from Algeria, based on photographic material and supplementing data which were extracted from citizen science observations. The provided material depicts the range expansion of the species throughout the coastal area of the country and provides new insight on the current distribution of the insect in the Mediterranean region, as well as in the continent of Africa. In addition, hypotheses on the possible introduction routes of the black soldier fly in the southwestern Mediterranean region are briefly discussed.
\end{abstract}

KEY WorDS: Algeria, alien species, black soldier fly, Hermetia illucens, Stratiomyidae.

\section{INTRODUCTION}

The translocation of species to areas beyond their natural adapted range has been a topic of increasing global concern over the years, due to the numerous ecological impacts that are closely tied to such events (RICCIARDI, 2007; KUEFFER, 2017). Even though there are known cases where the deliberate or unintentional introduction of an alien species did not have a substantial effect on the environment, economy or human health (FOXCROFT and DOWNEY, 2008), others have been identified as a growing threat to biodiversity and ecosystem services around the world (GANDHI and HERMS, 2010; BELlARD et al., 2016). Thus, the study of this group of organisms remains essential and can be employed in identifying pathways of introduction and developing management plans to prevent their further spread.

A great number of insect species have been accidentally introduced and have consequently expanded their distribution in the Western Palearctic over the last years, such as the box tree moth, Cydalima perspectalis (Walker, 1859) (HADDAD et al., 2020), and the featherlegged fly, Trichopoda pennipes (Fabricius, 1781) (KAZILAS et al., 2020). The black soldier fly, Hermetia illucens (Linnaeus, 1758) is a polysaprophagous species of Nearctic origin, which is nowadays regarded as cosmopoli$\tan$ (MARSHALL et al., 2015). The presence of the fly is known from a large part of Europe, including various Mediterranean countries, such as Malta (LINDNER, 1936), Spain (PERIS, 1962), France (ChEVIN, 1986), Portugal (CARLES-TOLRÁ, 2001), Italy (MASON, 2013), and Greece (TSAGKARAKIS et al., 2015). In Africa, the spe- cies has been recorded from several localities in the central and southern part of the continent, namely: Madagascar (LECLERCQ, 1997; OLIVEIRA et al., 2015), Burundi, Cameroon, Ivory Coast, Liberia (LECLERCQ, 1997), Guinea (LARDÉ, 1990), Ghana, Mali (DEVIC and MAQUART, 2015), South Africa (MARSHALL et al., 2015) and Réunion island (INPN, 2019). In addition, MAQUART et al. (2020) reported additional sightings of the fly in Africa, which also included the countries of Ethiopia, Kenya, Namibia, Rwanda, Senegal, Tanzania and Uganda. Lastly, in the northern part of the continent, the presence of the H. illucens is known from Morocco (MAQUART et al., 2020), while it has not yet been found in any other country of that region.

Even though the black soldier fly appears to have been established in various parts of the world, it still has not been recognized as a pest (FURMAN et al., 1959) or a threat to the native species in the introduced areas (MAQUART et al., 2020). The species has been observed in rice fields of Northern Italy in the past (GOIDANICH, 1939), but no evidence of damage to plants has been documented. On the contrary, the ability of the larva of $H$. illucens to consume decaying organic matter has deemed this species as a commercially important bioconverter (GAO et al., 2019). The fly is also of particular interest for its applications in house fly infestation and manure control (SHEPPARD, 1983; SHEPPARD et al., 1994), production of food supplements (NEWTON et al., 1977; BONDARI and SHEPPARD, 1981) and composting (LALANDER et al., 2015).

Herein we present the first record of H. illucens for Algeria, extending its known distribution range in Africa. 


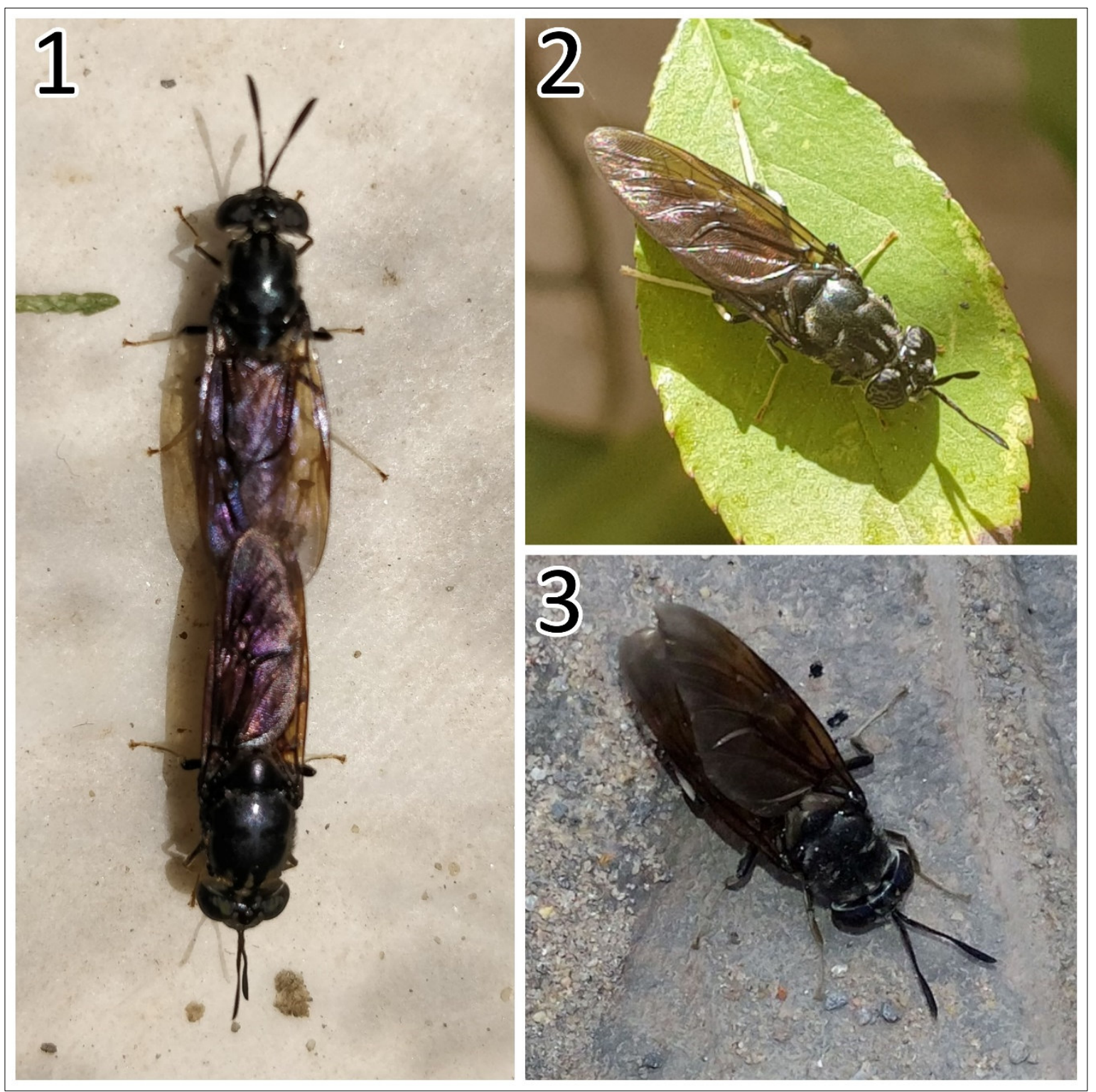

Fig. I - Individuals of Hermetia illucens photographed in situ from three localities in Algeria: Annaba (1), El Biar (2), Bir El Djir (3). Photos by S. Samy (1), A. Andaloussi (2) and S. Kernane (3).

\section{MATERIALS AND METHODS}

The present publication is based entirely on citizen science records, which were extracted from the iNaturalist online platform. All records were obtained after personal communication with their respective observer and identified based on species diagnoses of (ROZKOŠNÝ, 1982; OliveIRA et al., 2016; DUZELL, 2019; LESSARD et al., 2019). In order to avoid errors in species determination, we only included photographic material of sufficient quality, thus excluding a few vague observations from the current study.

\section{RESULTS}

Apart from its distinct morphological features, the fact that $H$. illucens is the only representative of the ge- nus Hermetia in the Palearctic region was taken into consideration (ROZKOŠNÝ and NARTSHUK, 1988; WOODLEY, 2001; STÅHLS et al., 2020), thus further confirming the accurate identification of the presented records.

A total of three citizen science records of the occurrence of $H$. illucens in Algeria are presented:

Annaba (36.91534 , 7.761994), 28.v.2020, S. Samy, 2 individuals in copula (iNaturalist) (https:// www.inaturalist.org/observations/47610018) (Fig. I, 1).

Bir El Djir, Oran $\left(35.723778^{\circ},-0.560600^{\circ}\right)$, 18.x.2018, S. Kernane, 1 individual (iNaturalist) (https://www.inaturalist.org/observations/24207025) (Fig. I, 3).

El Biar, Algiers $\left(36.773554^{\circ}, 3.043631^{\circ}\right)$, 22.vi.2020, A. Andaloussi, 1 individual (iNaturalist) (https:// www.inaturalist.org/observations/50534522) (Fig. I, 2). 


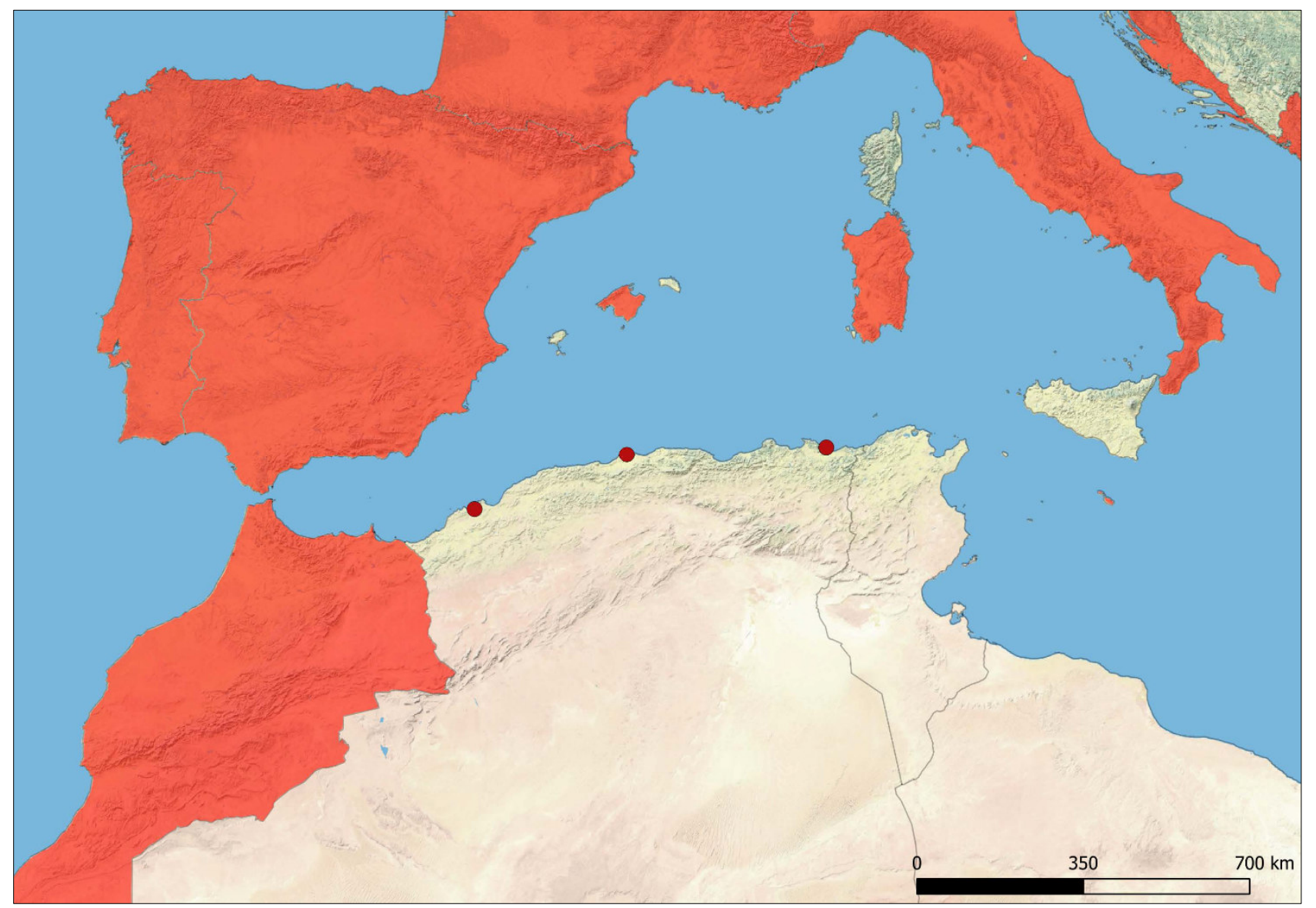

Fig. II - Physical map of the southwestern Mediterranean, where Hermetia illucens has been recorded. The red dots represent the new records of the fly from Algeria, while the red shaded areas indicate the countries where the presence of the species is already known.

\section{DISCUSSION}

The time period of the presented observations, which exceeds two consecutive years, suggests that $H$. illucens has formed established populations in the studied areas. All of the aforementioned records are distributed throughout the Mediterranean part of Algeria (Fig. II), in large cities that have commercial ports, which could support the hypothesis of an accidental introduction through maritime trade routes, possibly from another Western Mediterranean country such as Morocco, Malta, Italy, France, Spain or Portugal. Alternatively, the Black soldier fly could have actively dispersed to Algeria from Morocco throughout northwestern Africa, while a central African origin is less likely, given that the southern part of the country is covered by the Sahara desert. However, a genetic analysis of these populations is necessary in order to determine their exact origin, since a combination of these two scenarios is also possible.

The presence of $H$. illucens in North Africa is also confirmed by Fauna Europaea, although after personal communication with Dr. Thomas Pape, detailed distributional records of the species' presence in the region could not be found. The presence of Black soldier fly in Algeria could be subject to further research, especially on field, in order to ascertain the exact distribution of the species in North Africa and especially on the coastal areas of Tunisia,
Libya and Egypt, thus concluding if the species has a continuous spread throughout the southern Mediterranean.

\section{ACKNOWLEDGEMENTS}

We would kindly like to thank all aforementioned citizen scientists for providing us with their precious photographic material and data. Furthermore, we would also like to wholeheartedly thank Dr. Pierre-Olivier Maquart, Dr. Thomas Pape, for their guidance and clarifications on the species presence in Morocco and North Africa respectively, as well as the two anonymous reviewers for their valuable comments and corrections to the manuscript.

\section{REFERENCES}

Bellard C., CASsey P., BlackBuRn T.M., 2016 - Alien species as a driver of recent extinctions. - Biology letters, 12 (2): 20150623.

BONDARI K., SHEPPARD D.C., 1981 - Soldier fly larvae as feed in commercial fish production. - Aquaculture, 24: 103-109.

CARLES-TOLRÁ M., 2001 - Nuevos datos sobre dipteros 
iberobaleares (Diptera: Orthorrhapha y Cyclorrhapha). - Bol. Asoc. Esp. Entom., 25: 53-95.

CHEVIN H., 1986 - Présence d'Hermetia illucens (L.) en Charente-Maritime (Dipt. Stratiomyidae). - L'Entomologiste, 42 (2): 76.

DEVIC E., MAQUART P.O., 2015 - Dirhinus giffardii (Hymenoptera: Chalcididae), parasitoid affecting black soldier fly production systems in West Africa. - Entomologia, 3 (284): 25-27.

DuZELl M., 2019. - "Hermetia illucens" (On-line), Animal Diversity Web. Available from: https://animaldiversity.org/accounts/Hermetia_illucens [accessed 25 August, 2020].

FOXCROFT L.C., DOWNEY P.O., 2008 - Protecting biodiversity by managing alien plants in national parks: perspectives from South Africa and Australia. In: Plant invasions: Human perception, ecological impacts and management. Backhuys Publishers, Leiden, pp.387-403.

FURMAN D.P., Young R.D., CATTS P.E., 1959 - Hermetia illucens (Linnaeus) as a factor in the natural control of Musca domestica Linnaeus. - Journal of Economic Entomology, 52 (5): 917-921.

GANDHI K.J., HERMS D.A., 2010 - Direct and indirect effects of alien insect herbivores on ecological processes and interactions in forests of eastern North America. - Biological Invasions, 12 (2): 389-405.

GaO Z., WANQIANG W., XiaOheng L., Fen Z., Wen L., XIAO-PING W., ChaOliang L., 2019 - Bioconversion performance and life table of black soldier fly (Hermetia illucens) on fermented maize straw. - Journal of Cleaner Production, 230: 974-980.

GOIDANICH A., 1939 - Contributi alla conoscenza dell'entomofauna di risaia. 1. Gli Straziomidi: mancati nemici del riso. - Risicoltura, 29: 221-230.

HADDAD K., KALAENTZIS K., DEMETRIOU J., 2020 - On track to becoming a cosmopolitan invasive species: First record of the box tree moth Cydalima perspectalis (Lepidoptera: Crambidae) in the African continent. - Entomologia Hellenica, 29(2): 27-32.

INPN, 2019 - Available from: https://inpn.mnhn.fr/espece/cd_nom/217341. [accessed 25 October, 2020].

KAZILAS C., DEMETRIOU J., KALAENTZIS K., 2020 - Filling the gaps in the distribution of an alien species: The case of the feather-legged fly Trichopoda pennipes (Diptera: Tachinidae) in the Western Palearctic. - Entomologia Hellenica, 29 (1): 8-16.

KUEFFER C., 2017 - Plant invasions in the Anthropocene. - Science, 358 (6364): 724-725.

LALANDER C.H., FIDJELAND J., DiENER S., ERIKSSON S., VINNERÅs B., 2015 - High waste-to-biomass conversion and efficient Salmonella spp. reduction using black soldier fly for waste recycling. - Agronomy for Sustainable Development, 35 (1): 261-271.

LARDÉ G., 1990 - Recycling of coffee pulp by Hermetia illucens (Diptera: Stratiomyidae) larvae. - Biological wastes, 33 (4): 307-310.

LECLERCQ M., 1997 - About Hermetia illucens (Linnaeus, 1758) (soldier fly) (Diptera, Stratiomyidae: Hermetiinae). - Bulletin et Annales de la Societe Royale Belge d'Entomologie, 133: 275-282.
Lessard B.D., YeATES D.K., WoOdLEY N.E., 2019 Revision of the Hermetiinae of Australia (Diptera: Stratiomyidae). - Austral. Entomology 58 (1): 122136.

LINDNER E., 1936 - Die amerikanische Hermetia illucens L. im Mittelmeergebiet (Stratiomyiidae, dipt.). - Zoologischer Anzeiger, 113: 335-336.

MAQUART P.O., RICHARD D., WILLEMS J., 2020 - First record of the Black Soldier Fly, Hermetia illucens, in the Western regions of France (Vendée, Loire-Atlantique, Ille-et-Vilaine) with notes on its worldwide repartition (Diptera, Stratiomyidae). - Bulletin de la Société entomologique de France, 125 (1): 13-18.

MARSHAll S.A., WoOdLEY N.E., HAUSER M., 2015 The historical spread of the Black Soldier Fly, Hermetia illucens (L.) (Diptera, Stratiomyidae, Hermetiinae), and its establishment in Canada. - The Journal of the Entomological Society of Ontario, 146: 51-54.

MASON F., 2013 - Updated Italian checklist of soldier flies (Diptera, Stratiomyidae). - ZooKeys, 336: 61.

NeWTon G.L., Booram C.V., BARKer R.W., Hale O.M., 1977 - Dried Hermetia illucens larvae meal as a supplement for swine. - Journal of Animal Science, 44 (3): 395-400.

OLIVEIRA F., DOELLE K., List R., O’REILLY J.R., 2015 Assessment of Diptera: Stratiomyidae, genus Hermetia illucens (L., 1758) using electron microscopy. J. Entomol. Zool. Stud, 3 (5): 147-152.

OLIVEIRA F.R., DOELLE K., SMITH R.P., 2016 - External Morphology of Hermetia illucens Stratiomyidae: Diptera (L.1758) Based on Electron Microscopy. Annual Research \& Review in Biology, 9 (5): 1-10.

PERIS S.V., 1962 - Hermetia illucens (L.) por primera vez en España (Dipt. Stratiomyidae). - Publ. Inst. Biol. Apl., 33: 51-56.

RICCIARDI A., 2007 - Are modern biological invasions an unprecedented form of global change? - Conservation Biology, 21 (2): 329-336.

ROZKOŠNÝ R., 1982 - A Biosystematic study of the European Stratiomyidae (Diptera). Volume 2.: Clitellariinae, Hermetiinae, Pachygasterinae and Bibliography. Series Entomologica, XXV+ 431 pp.

ROZKOŠNÝ R., NARTSHUK E.P., 1988 - Family Stratiomyidae. In: Catalogue of Palaearctic Diptera. Vol. 5, Akadémiai Kiadó, Budapest, pp.42-96.

SHEPPARD C., 1983 - House fly and lesser fly control utilizing the black soldier fly in manure management systems for caged laying hens. - Environmental entomology, 12 (5): 1439-1442.

Sheppard D.C., Newton G.L., ThOMPSON S.A., SAVAGE S., 1994 - A value added manure management system using the black soldier fly. - Bioresource technology, 50 (3): 275-279.

STÅHLS G., MEIER R., SANDROCK C., HAUSER M., ŠAŠIĆ Zorić L., LAIHO E., ArALIC A., DODEROVIĆ J., BADENHORST R., UNADIREKKUL P., MOHD ADOM N.A.B., WEIN L., RichardS C., TOMBERLIN J.K., RoJo S., VESElić S., PARVIAINEN T., 2020 - The puzzling mitochondrial phylogeography of the black soldier fly (Hermetia illucens), the commercially most 
important insect protein species. - BMC Evolutionary Biology, 20: 1-10.

TSAGKARAKIS A.E., ARAPOSTATHI E.I., Strouvalis G.I., 2015. - First record of the black soldier fly, Hermetia illucens, in Greece. - Entomologia Hellenica,
24 (2): 27-30.

WoODLEY N.E., 2001 - A world catalog of the Stratiomyidae (Diptera). - Myia, 11: 1-473. 